I shall not continue this embarrassing list. A proper translation of about ten of the most important texts and a substantial analysis of Snecvlict's role could have provided a valuable contribution to research on the early evolution of the $\mathrm{CCP}$ and the significance of the ECCI in China. The almost 200 pages long introductory chapter contributes elements of a useful analysis and paraphrases some of the sources transcribed and translated elsewhere in the volumes.

The volumes touch on key issues of general concern in the research of the early CCP. However, the project has evidently not been sufficiently developed and the necessary expertise has not been drawn in to ensure that it could be carried out fruitfully. It seems that the editor has been under time pressure and that a breathing space could have been provided him with time to make proper arrangements for the research. The whole concept of the edition seems to have been vaguely formulated from the outset. But if that is normal practice with this type of editions, then so be it.

Flemming Christiansen

KIFT, DaGmar. Arbeiterkultur im gesellschaftlichen Konflikt. Die englische Music Hall im 19. Jarhundert. [Schriften des Fritz-Hülser-Instituts für Arbeiterliteratur.] Klartext, Essen 1991. 237 pp. DM 38.00.

The British public is inclined to romanticize the music hall $-\mathbf{a}$ rather curious phenomenon in view of the fact that few of them can ever have experienced its popular appeal, its alleged close rapport between the artistes and the audience, or the sentimentality of its repertoire. The nostalgia for things unseen and unheard must derive either at second hand from the memory of others who survived and remembered or from the surviving songs. No doubt only the best of these have survived with their universal appeal in describing the lives and loves of ordinary men and women - human beings like the hearers themselves.

Music halls have, however, also become a favourite field of study for the social historian. It is not only the mass audience which interests him or her, made up of the ordinary people about whom so little is known, but also the concept of a counter-culture, a culture not controlled by the hegemonial classes and in some respects opposed to them. Were the music halls a focus of rebellion, or at least a symbol of disaffection and independence?

Dagmar Kift has much sympathy for the current literature, but is also critical of it in some respects. Above all, she complains, and not without reason, that it tends to concentrate on London, and London was in many respects different from the provinces. This study deliberately sets out to focus on the provinces, which in this context tends to mean some of the larger cities of Lancashire and the West Riding of Yorkshire, together with Glasgow.

Among the obvious differences between these and the capital is the fact that whereas in London there was a chronological sequence from the "free and easies" via the concert room or singing room to the music hall proper, in the provinces these tended to co-exist, the music halls in the centres of the towns not fully driving out the less ambitious public houses with entertainment in the lesser streets in the suburbs. By the 1890 s, which mark a turning point in several respects, there was a certain convergence, however, especially in the programmes, which is not entirely surprising in view of the chains of music halls which some entreprencurs had been 
able to build up. West End music halls by then were frequented by men-abouttown, among others, and by ladies of doubtful virtue. The apostles of moral rectitude who made it their business to monitor these premises could, not without reason, point to these places as recruiting ground for the devil, and respectable women were not likely to be seen in them. In the provinces, however, and especially in towns with large female employment in the textile mills, whole family groups of young women, would attend without damage to their reputation, though it was hardly likely that women with children at home would be among them. The occasional innuendo which was part of the repertoirc of music hall songs does not seem to have met with much opposition from the mixed provincial audiences.

Opposition there was, from various middle-class quarters, and it is this which has heiped to provide the aura of rebelliousness. But it is clear from this study that opposition was not class-based as such, and with occasional exceptions in Glasgow, Bradford, and Sheffield, there seemed to have been no desire on the part of (middlc-class) magistrates to obstruct the music halls even after they were given the power to license them. Instead, the opposition came largely from evangelicals, from those in favour of more "moral" entertainment, and above all from the temperance movement, for music halls were associated with beer drinking, either by charging entry by means of a drink voucher or by an active policy of a lively bar trade during the performance.

Much of modem social literature is curiously ambivalent about the working-class drink problem. The temperance movement generally gets short shrift as part of the hegemonial attempt to dominate by cultural aggression, and the present author does certainly not dissent from that view. But drink was a real problem in numerous families. The picture of the wife anxiously waiting outside the beerhouse on the cvening of payday, to see how much would be left to feed the family including the children the rest of the week, was a common enough phenomenon; yet much of the socialist literature which often professes to be closely identified with the feminist movement is remarkably silent on this aspect. Respectable and even classconscious working men were as determined to avoid the danger of alcohol as were middle-class do-gooders. The question of how the weekly income was spent is also raised by the cost of entrance tickets at $3 \mathrm{~d}$., $6 \mathrm{~d}$. or upward. Bought by apprentices as well as by fathers of families, they show that much of the working class was far from starvation, and not too tired to be entertained in an evening.

Another source of opposition was the rival theatre, and this was purely commercial in origin. In this context $\mathrm{Dr}$ Kift takes us with much skill through the complex and labyrinthine licensing provisions governing theatres and sellers of alcohol: it is a virtuoso performance for someone not brought up to the intricacies and unique logic of English (and Scottish) licensing laws.

Were the songs rebellious, independent, defiant of authority? Dr Kift, like others before her, is rather ambivalent. She follows the trend in assuming that the more jingoistic tendencies after the Boer War met with little response, but the truth is that even before, the tenor of the performanes was not political, and it was economic only insofar as problems of making ends meet or of relations with the boss form part of the preoccupation of the average worker and lower middle-class employec, and found their reflection in the themes presented from the stage. It would then be interesting to know who wrote the songs, and who the singers were - though the life stories of some of the more prominent ones are given in this volume. Was the lure of the stage classless? Did the actors, jugglers and singers of the legitimate music hall consider that they had bettered themselves from their 
proletarian origins and feel condescension in the pretence to be still part of the "people"? Is there much difference in the themes and attitudes of the popular music-hall songs to the popular sentiments expressed, say, in the Beggar's Opera? Certainly, attempts to suppress the music hall by the use of the Licensing Acts brought forth a strong popular reaction in their favour - but we do not know how many objected to these demonstrations, and why.

Other puzzles remain. Were there really houses holding audiences of 2,000 or 3,000 , placed in the narrow strect-network of the industrial towns in the North, and if so, could anyone hear what was being said or sung on the stage - particularly when drinks were being served at the same time and people sat at tables rather than in narrow serried rows, as in theatres provided later? Did people go there for the songs, the circus acts, the glimpses of classical theatre - or just the convivial atmosphere? Why was it necessary to add exhibitions, zoos, galleries and other extraneous matter to the largest and most successful of the music halls?

Popular "culture" is not easy to fit into a class pattern. The music hall had its lower middle-class addicts as well as its working men and women, and possibly these predominated in some cities and some parts of London. Against this, there were numerous carnest working men and their families who were not attracted and who deplored the waste of time and money, though they would probably not have favoured the prohibition of these establishments. Moreover, it was not necessarily the employers of labour, or even the titled upper classes, who opposed free and easy, raucous, alcoholic forms of entertainment. The opposition frequently came from the professional middle classes, from clergymen, journalists, medical or legal gentlemen and their ladies, some, no doubt, full of goodwill for the lower orders and conscious of thcir exploitation by an increasingly capitalistic class of music hall proprietors. On the issue of freedom, perhaps, there was a parting of the ways, only middle-class people thinking of prohibition what they did not like. But as a cultural phenomenon, the music hall remains ambiguous.

Much of this ambiguity is found in this well-researched, thoughtful, wellbalanced account. The provincial music hall, in particular, deserved to be rescued from oblivion, and it is well to show London-based historians that there was history also north of Watford. This is part of a complex picture, but many of its complexities still await resolution.

Sidney Pollard

\section{Gruber, Helmut. Red Vienna. Experiment in Working Class Culture 1919-1934. Oxford University Press, New York [etc.] 1991. x, 270 pp. III. £25.00.}

In February 1934 the uprising of Austrian workers against the authoritarian government ended with the death of several hundred soldiers and civilians, the removal of the remaining democratic guarantecs, and the destruction of the far-reaching network of labour institutions throughout the country. Four years later Hitler proclaimed the Anschluss of his former homeland. In labour history the February uprising has long been considered an impressive, heroic act of defence, but one without any chance of success during the "wave" of fascistic take-overs. But this leaves unexplained how a political movement with more than 600,000 party members, the strongest faction in parliament, allicd with a unified, totally social- 